\title{
Effect of ions on the measurement of sulfuric acid in the CLOUD experiment at CERN
}

\author{
L. Rondo ${ }^{1}$, A. Kürten ${ }^{1}$, S. Ehrhart ${ }^{1}$, S. Schobesberger ${ }^{2}$, A. Franchin ${ }^{2}$, H. Junninen ${ }^{2}$, T. Petäjä̈ ${ }^{2}$, M. Sipilä2 ${ }^{2}$, \\ D. R. Worsnop ${ }^{2,3}$, and J. Curtius ${ }^{1}$ \\ ${ }^{1}$ Institute for Atmospheric and Environmental Sciences, Goethe University Frankfurt am Main, \\ 60438 Frankfurt am Main, Germany \\ ${ }^{2}$ Department of Physics, University of Helsinki, P.O. Box 64, 00014 Helsinki, Finland \\ ${ }^{3}$ Aerodyne Research, Inc., 45 Manning Road, Billerica, MA 01821, USA \\ Correspondence to: L. Rondo (1.rondo@iau.uni-frankfurt.de)
}

Received: 6 May 2014 - Published in Atmos. Meas. Tech. Discuss.: 3 July 2014

Revised: 26 September 2014 - Accepted: 30 September 2014 - Published: 19 November 2014

\begin{abstract}
Ternary aerosol nucleation experiments were conducted in the CLOUD chamber at CERN in order to investigate the influence of ions on new particle formation. Neutral and ion-induced nucleation experiments, i.e. without and with the presence of ions, respectively, were carried out under precisely controlled conditions. The sulfuric acid concentration was measured with a chemical ionisation mass spectrometer (CIMS) during the new particle formation experiments. The added ternary trace gases were ammonia $\left(\mathrm{NH}_{3}\right)$, dimethylamine (DMA, $\left.\mathrm{C}_{2} \mathrm{H}_{7} \mathrm{~N}\right)$ or oxidised products of pinanediol $\left(\mathrm{PD}, \mathrm{C}_{10} \mathrm{H}_{18} \mathrm{O}_{2}\right)$. When pinanediol was introduced into the chamber, an increase in the mass spectrometric signal used to determine the sulfuric acid concentration $\left(m / z, 97\right.$, i.e. $\left.\mathrm{HSO}_{4}^{-}\right)$was observed due to ions from the CLOUD chamber. The enhancement was only observed during ion-induced nucleation measurements by using either galactic cosmic rays (GCRs) or the proton synchrotron (PS) pion beam for the ion generation, respectively. The ion effect typically involved an increase in the apparent sulfuric acid concentration by a factor of $\sim 2$ to 3 and was qualitatively verified by the ion measurements with an atmosphericpressure interface-time of flight (APi-TOF) mass spectrometer. By applying a high-voltage (HV) clearing field inside the CLOUD chamber, the ion effect on the CIMS measurement was completely eliminated since, under these conditions, small ions are swept from the chamber in about $1 \mathrm{~s}$. In order to exclude the ion effect and to provide corrected sulfuric acid concentrations during the GCR and PS beam nucleation experiments, a parameterisation was derived that
\end{abstract}

utilises the trace gas concentrations and the UV light intensity as input parameters. Atmospheric sulfuric acid measurements with a CIMS showed an insignificant ion effect.

\section{Introduction}

Atmospheric aerosols have an important effect on clouds and climate, with secondary aerosol particles contributing significantly to the global concentration of cloud condensation nuclei $(\mathrm{CCN})$ via new particle formation (Kulmala et al., 2004; Merikanto et al., 2010). From both field and laboratory measurements, it has been well established that sulfuric acid $\left(\mathrm{H}_{2} \mathrm{SO}_{4}\right)$ plays a crucial role in atmospheric nucleation (Curtius, 2006; Riipinen et al., 2007; Kuang et al., 2008). However, binary nucleation of sulfuric acid and water vapour can be ruled out as a plausible mechanism to explain observed boundary layer nucleation rates (Kirkby et al., 2011). The presence of ternary substances like ammonia (Benson et al., 2009; Kirkby et al., 2011) or oxidised organic compounds (Zhang et al., 2004; Metzger et al., 2010; Riccobono et al., 2012, 2014; Schobesberger et al., 2013) can elevate the particle formation rates by orders of magnitude. Yet so far the physico-chemical processes taking place in atmospheric boundary layer particle formation remain unknown and questions still remain on the exact contribution of ternary substances and on the role of ions in atmospheric nucleation (Kulmala, 2003; Lovejoy et al., 2004). One goal of the CLOUD (Cosmics Leaving OUtdoor Droplets) experiment 
at CERN is to investigate to what extent the presence of ions affects new particle formation at atmospherically relevant conditions (Kirkby et al., 2011; Schobesberger et al., 2013; Almeida et al., 2013). At CLOUD, neutral and ioninduced nucleation experiments are carried out in an aerosol chamber under precisely controlled conditions. Trace gases are added into the CLOUD chamber in order to investigate their influence on the nucleation. The source of ions in the chamber is either galactic cosmic rays (GCRs) or both GCR and CERN's proton synchrotron (PS) pion beam (Duplissy et al., 2010; Kirkby et al., 2011). Highly accurate and precise measurements of gaseous $\left[\mathrm{H}_{2} \mathrm{SO}_{4}\right]$ are required in order to interpret the data and for deriving parameterisations of the nucleation rate for certain conditions. Sulfuric acid concentration measurements are therefore performed with a chemical ionisation mass spectrometer (CIMS; Kürten et al., 2012).

In this paper, we describe the effect of ionising radiation on the sulfuric acid measurements performed by the CIMS instrument. During nucleation experiments with oxidation products of pinanediol, the mass spectrometric sulfuric acid signal ( $\mathrm{HSO}_{4}^{-}$ions) showed an increase due to the presence of ions in the chamber. The characteristics of the increased signal lead to the conclusion that $\mathrm{HSO}_{4}^{-}$ions from the chamber were interfering with the product ions from the CIMS ion reaction zone. In order to verify this assumption, dedicated tests with the CIMS and the pion beam were performed. Surprisingly, the ion contribution was only detectable under the presence of oxidised organic compounds. Additionally, the atmospheric-pressure-interface time-of-flight mass spectrometer (APi-TOF; Junninen et al., 2010) measurements of ionic clusters confirmed that the enhanced $\mathrm{HSO}_{4}^{-}$signal is coming directly from the chamber in the presence of oxidised organic compounds. In order to exclude the ion effect and to derive the correct sulfuric acid concentration for the ternary pinanediol nucleation runs, a parameterisation was developed.

\section{Methods}

\subsection{CLOUD chamber measurements}

Nucleation experiments were carried out using the CLOUD chamber at CERN (Kirkby et al., 2011). The electropolished stainless steel chamber of $26 \mathrm{~m}^{3}$ volume provides an ultraclean environment where selected trace gases and ultrapure humidified synthetic air can be continuously supplied. Welldefined amounts of $\mathrm{H}_{2} \mathrm{SO}_{4}$ are produced in situ from $\mathrm{SO}_{2}$ and $\mathrm{OH}$ by means of internal ultraviolet (UV) illumination from a fibre-optic system producing $\mathrm{OH}$ from ozone and $\mathrm{H}_{2} \mathrm{O}$ (Kupc et al., 2011). As a source of ionising radiation for ion-induced nucleation measurements, an adjustable pion beam from the CERN proton synchrotron (PS) is used in order to simulate and enhance the natural cosmic radiation. For the so-called GCR ion-induced nucleation experiments
(GCR runs), the pion beam is turned off and the chamber is only irradiated by the natural GCRs that enter the chamber, while for ion-free nucleation experiments (neutral runs), an internal electric clearing field, with a total potential difference of $60 \mathrm{kV}$, was used to sweep any ions out of the chamber within less than $1 \mathrm{~s}$ (Kirkby et al., 2011). The contents of the CLOUD chamber are continuously mixed by means of two fans (Voigtländer et al., 2012) and are analysed using a wide variety of instruments, each connected to a separate $0.75 \mathrm{~m}$ long sampling probe protruding into the chamber. The instrumentation includes several condensation particle counters (CPCs), mass spectrometers and electrical mobility analysers. Organic trace gases were monitored with a proton-transfer-reaction time-of-flight mass spectrometer (PTR-TOF-MS; Schnitzhofer et al., 2014), and aerosol particle concentrations were measured, starting at particle diameter sizes smaller than $2 \mathrm{~nm}$ (Wimmer et al., 2013).

During the CLOUD-04 campaign in June and July 2011, data of multi-component nucleation were obtained at the CLOUD chamber involving sulfuric acid and water vapour and adding either ammonia, dimethylamine or biogenic organic vapours (pinanediol, PD). PD is a surrogate firstgeneration product from the important biogenic vapour $\alpha$ pinene, which is further oxidised by ozone and $\mathrm{OH}$ radicals to form more highly oxidised organic substances. Ammonia and dimethylamine concentrations were determined with an ion chromatograph (Praplan et al., 2012) while concentrations of organic compounds were measured with a PTRTOF-MS (Schnitzhofer et al., 2014). The nucleation events were started by switching on the UV light, which initiates the $\mathrm{OH}$ formation from ozone photolysis and leads to the production of $\mathrm{H}_{2} \mathrm{SO}_{4}$ (Kupc et al., 2011). While pinanediol is present in the chamber, the produced $\mathrm{OH}$ radicals would also contribute to reactions with pinanediol, competing in this way with the sulfuric acid production (Schobesberger et al., 2013; Riccobono et al., 2014).

\section{$2.2 \mathrm{H}_{2} \mathrm{SO}_{4}$ measuring technique}

A negative-ion detection CIMS instrument was used to measure the concentration of gaseous $\mathrm{H}_{2} \mathrm{SO}_{4}$ with a detection limit of $\sim 1 \times 10^{5}$ molecule $\mathrm{cm}^{-3}$ and $30 \mathrm{~s}$ integration time. This system utilises a specific ion-molecule reaction to convert electrically neutral $\mathrm{H}_{2} \mathrm{SO}_{4}$ molecules into bisulfate $\mathrm{HSO}_{4}^{-}\left(\mathrm{m} / z\right.$ 97) ions, using $\mathrm{NO}_{3}^{-}$as the ionising agent. This technique has been used previously in many other studies for gaseous or aerosol measurements (Viggiano and Arnold, 1983; Eisele and Tanner, 1993; Berresheim et al., 2000; Petäjä et al., 2009). The CIMS system (THS Instruments LLC, USA) contains a quadruple mass filter and a Channeltron detector for the quantification of analyte ions (Huey, 2007). In addition to the basic components, a collision dissociation chamber (CDC) consisting of an octopole, is used to remove weakly bonded water and nitric acid molecules from the core ions via energetic collisions (Tanner et al., 1997). 
The ion source that is used to generate the primary ions is a newly developed corona ion source (Kürten et al., 2011). For a known ion molecule residence time in the flow reactor and rate constant, the sulfuric acid concentration can be calculated by the ratio of the product ions ( $\mathrm{HSO}_{4}^{-}$ions) to educt ions ( $\mathrm{NO}_{3}^{-}$ions) count rates. In order to avoid any possible damage to the Channeltron detector due to the high count rate of the $\mathrm{NO}_{3}^{-}$ions, we measure the isotope at $m / z 64, \mathrm{~N}^{18} \mathrm{OO}_{2}^{-}$ (Kürten et al., 2012). The ion-molecule reactions between the reagent ions and the neutral compound to be detected and quantified occur in the flow reactor according to Reaction (1):

$$
\begin{aligned}
\mathrm{H}_{2} \mathrm{SO}_{4}+\mathrm{NO}_{3}^{-}\left(\mathrm{HNO}_{3}\right)_{n} & \rightarrow \mathrm{HSO}_{4}^{-}\left(\mathrm{HNO}_{3}\right)_{n-m+1} \\
& +m\left(\mathrm{HNO}_{3}\right)
\end{aligned}
$$

Subsequent to the formation of the bisulfate ion and nitric acid clusters within the CIMS flow reactor, the dissociation Reaction (R2) of the above bisulfate clusters takes place in the collision dissociation chamber, resulting in the detection of the $\mathrm{HSO}_{4}^{-}$.

$\mathrm{HSO}_{4}^{-}\left(\mathrm{HNO}_{3}\right)_{n-m+1} \rightarrow \mathrm{HSO}_{4}^{-}+(n-m+1) \cdot\left(\mathrm{HNO}_{3}\right)$

Electrostatic voltages applied to different parts of the ion source and the drift tube guide the primary ions into the sample flow, where they can interact with the $\mathrm{H}_{2} \mathrm{SO}_{4}$ molecules. At the end of the drift tube, primary and product ions are drawn into the vacuum chamber. Signals of the most prominent product and primary ions were recorded every few seconds, while a complete mass spectrum (up to $m / z \sim 250$ ) was recorded every few minutes, allowing for measurements in real time. For diffusion-controlled wall losses within the CIMS sampling line, the $\mathrm{H}_{2} \mathrm{SO}_{4}$ diffusion coefficient $\left(D=0.078 \pm 0.0546 \mathrm{~cm}^{2} \mathrm{~s}^{-1}\right.$ for $T=278 \mathrm{~K}$ and $\mathrm{RH}=38 \%$; see Hanson and Eisele, 2000), the sample flow rate $(Q=7.5 \pm 0.1 \mathrm{slpm})$ and the length of the sampling line $(L=0.9 \mathrm{~m})$ were taken into account. The transmission efficiency was calculated as $44 \%$ for laminar flow in a straight tube using the empirical equations given in Baron and Willeke (2001). The measured $\mathrm{H}_{2} \mathrm{SO}_{4}$ concentration is derived by multiplying the $\mathrm{HSO}_{4}^{-} / \mathrm{NO}_{3}^{-}$ratio by a calibration factor (Kürten et al., 2012). By performing a detailed calibration with a dedicated calibration source, uncertainties of reaction rate, reaction time and wall losses in the ion-molecule reactor do not influence the determination of the $\mathrm{H}_{2} \mathrm{SO}_{4}$ concentration. The calibration source is based on photolysing water vapour with a mercury lamp to generate a known and stable amount of $\mathrm{OH}$ radicals in front of the inlet. The produced $\mathrm{OH}$ radicals react with $\mathrm{SO}_{2}$ from a gas bottle in the presence of $\mathrm{O}_{2}$ and water vapour, resulting in known sulfuric acid concentrations. The CIMS instrument was calibrated before and just after the end of the CLOUD-04 campaign in order to assure high accuracy of the measurement.
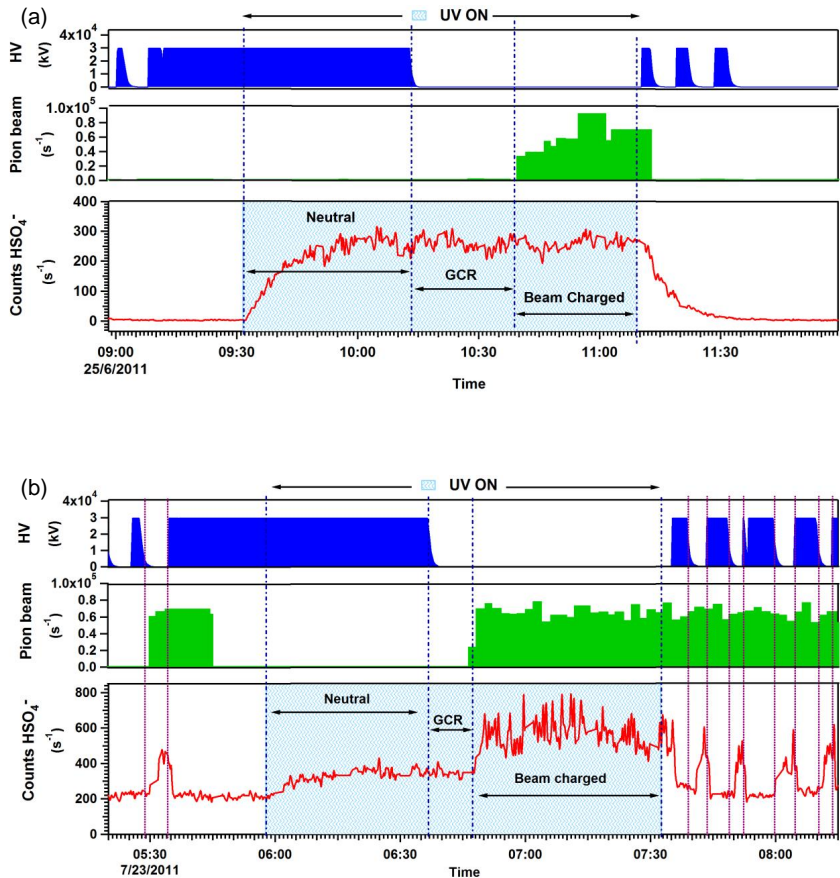

Figure 1. (a) Measurement of the CIMS bisulfate ion signal $\left(\mathrm{HSO}_{4}^{-}\right.$, red trace) during a typical binary nucleation experiment, displayed along with the variation of the pion beam intensity (green) and the clearing field high voltage (blue). (b) Measurement of the CIMS bisulfate ion signal for the ternary system (involving pinanediol) under the same beam conditions as in (a) (magenta vertical lines show the ion effect under no-UV conditions). The CIMS signal is influenced by additional $\mathrm{HSO}_{4}^{-}$ions from the chamber. This ion effect leads to an overestimation of the sulfuric acid concentration.

\section{Results}

\subsection{Sulfuric acid measurements during binary nucleation experiments}

The focus of the performed binary experiments $\left(\mathrm{H}_{2} \mathrm{SO}_{4}-\mathrm{H}_{2} \mathrm{O}\right)$ was the measurement of the nucleation rate under neutral, GCR and charged pion beam conditions. With the initial experimental conditions established in the chamber with constant $\mathrm{SO}_{2}$ and $\mathrm{O}_{3}$ concentration, temperature $(T)$, relative humidity $(\mathrm{RH})$ and stable UV lamp operation, a stable sulfuric acid concentration is typically reached within about $15 \mathrm{~min}$ after opening the shutter of the UV light source. Depending on the $\mathrm{H}_{2} \mathrm{SO}_{4}$ concentration, aerosol nucleation occurs at a constant rate (Kirkby et al., 2011; Riccobono et al., 2014). After switching off the UV light, the $\mathrm{OH}$ production stops and the $\mathrm{H}_{2} \mathrm{SO}_{4}$ concentration decreases to a background level due to condensation of $\mathrm{H}_{2} \mathrm{SO}_{4}$ on the chamber walls and dilution with freshly supplied air (Voigtländer et al., 2012). An overview of a typical binary run is given in Fig. 1a, which displays the clearing field voltage, the UV light intensity, the pion beam 


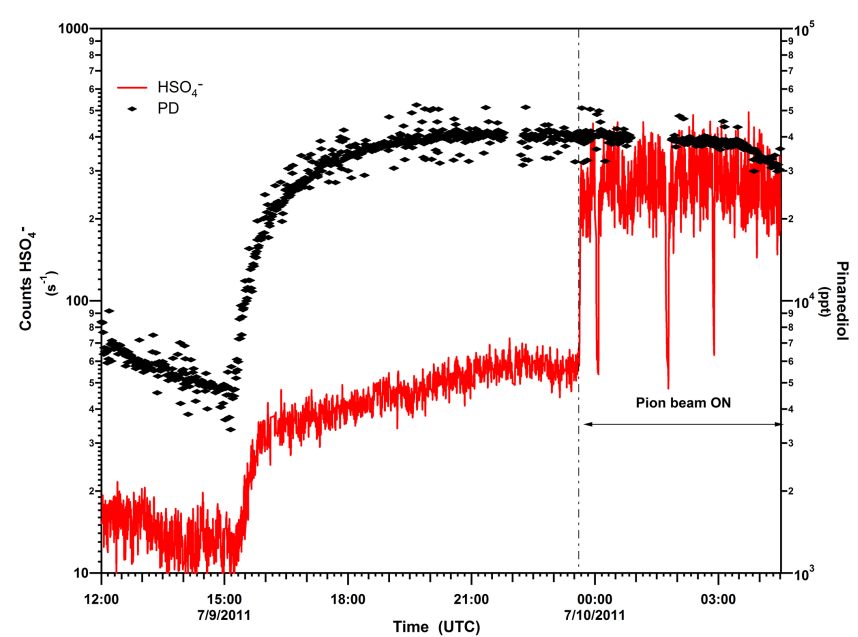

Figure 2. Enhancement of the $\mathrm{HSO}_{4}^{-}$count rate in the presence of pinanediol (PD) during an experiment without the presence of UV light. The observed $\mathrm{HSO}_{4}^{-}$enhancement in absence of UV light indicates the presence of a non-OH oxidant for $\mathrm{SO}_{2}$. The change in the PD concentration (factor of $\sim 8$ ) leads to an enhancement (factor of $\sim 5$ ) of the sulfuric acid background concentration $\left(\mathrm{HSO}_{4}^{-}\right.$count rate). For the period shown the $\mathrm{SO}_{2}$ (3 ppbv) and $\mathrm{O}_{3}(50 \mathrm{ppbv})$ mixing ratios remained stable; the clearing field high voltage was turned off during the first part of the experiment. The presence of ions generated by the pion beam (23:40 UTC and later) increased the CIMS signal by another factor of 5 , confirming the ion effect in the presence of PD.

intensity and the $\mathrm{HSO}_{4}^{-}$count rate used for deriving the sulfuric acid concentration. While the UV lights are turned off, there is a background of 5 to 7 counts per second for $\mathrm{HSO}_{4}^{-}$, resulting in a background sulfuric acid concentration of $2.5 \times 10^{5}$ molecule $\mathrm{cm}^{-3}$, which remains constant despite the changing clearing field voltage and pion beam intensity. Once the UV lights are switched on, the photooxidation of sulfur dioxide takes place in the presence of $\mathrm{O}_{3}$ and $\mathrm{H}_{2} \mathrm{O}$, producing an equilibrium sulfuric acid concentration around $2 \times 10^{7}$ molecule $\mathrm{cm}^{-3}\left(\mathrm{HSO}_{4}^{-}\right.$count rate $\left.\sim 300 \mathrm{~s}^{-1}\right)$. Similar to the situation under background conditions, the $\mathrm{H}_{2} \mathrm{SO}_{4}$ concentration is identical for neutral, GCR and charged pion beam conditions. After the UV lights are turned off, the $\mathrm{H}_{2} \mathrm{SO}_{4}$ steady state is disturbed and its concentration decreases due to loss onto the chamber walls and dilution. After some time $(\sim 1800 \mathrm{~s})$, the $\mathrm{H}_{2} \mathrm{SO}_{4}$ equilibrates back to the initial background concentration that was measured before starting the nucleation run.

\subsection{Sulfuric acid measurements during pinanediol nucleation experiments}

In order to study the effect of oxidised organic compounds on the nucleation rates pinanediol $\left(\mathrm{PD}, \mathrm{C}_{10} \mathrm{H}_{18} \mathrm{O}_{2}\right)$, vapour (Sigma Aldrich, 99\%) was introduced into the chamber (Schobesberger et al., 2013; Riccobono et al., 2014). The concentration of the oxidation products (OxOrgs) is varied by changing the UV illumination and the concentration of pinanediol. The presence of PD (up to $500 \mathrm{ppbv}$ ) increased the $\mathrm{HSO}_{4}^{-}$background intensity by as much as a factor of 40 in comparison to the chamber's neutral conditions without $\mathrm{PD}$, i.e. during nucleation experiments using only $\mathrm{H}_{2} \mathrm{SO}_{4}$ and $\mathrm{H}_{2} \mathrm{O}$, or $\mathrm{H}_{2} \mathrm{SO}_{4}, \mathrm{H}_{2} \mathrm{O}$ and $\mathrm{NH}_{3}$ (Fig. 1a and b). In particular, the enhancement of the $\mathrm{HSO}_{4}^{-}$background signal is confirmed by the data shown in Fig. 2. During this experiment no UV light was present. However, the increase in the PD level resulted in a clear enhancement of the bisulfate signal. An additional increase in the $\mathrm{HSO}_{4}^{-}$count rate is observed in the presence of the pion beam. The first increase in Fig. 2 suggests that another pathway exists for the production of $\mathrm{H}_{2} \mathrm{SO}_{4}$ besides the reaction between $\mathrm{OH}$ and $\mathrm{SO}_{2}$. It has been shown recently that stabilised Criegee intermediates produced from reactions between alkenes and ozone have the capacity to oxidise $\mathrm{SO}_{2}$ (Mauldin III et al., 2012). However, since PD does not react with ozone due to its lack of a double bond, organic impurities (alkenes) (Schnitzhofer et al., 2014) fed into the chamber along with the PD could account not only for the production of Criegee intermediates but also for the production of $\mathrm{OH}$ via ozonolysis of these alkenes (Kroll et al., 2001) and the subsequent generation of sulfuric acid (Riccobono et al., 2014). The following simplified scheme summarises the possible reactions:

$$
\begin{gathered}
\text { Alkenes }+\mathrm{O}_{3} \rightarrow \mathrm{sCI}+\mathrm{OH}, \\
\mathrm{sCI}+\mathrm{SO}_{2} \rightarrow \mathrm{SO}_{3}, \\
\mathrm{OH}+\mathrm{SO}_{2} \rightarrow \mathrm{H}_{2} \mathrm{SO}_{4}, \\
\mathrm{SO}_{3}+\mathrm{H}_{2} \mathrm{O} \rightarrow \mathrm{H}_{2} \mathrm{SO}_{4} .
\end{gathered}
$$

These organic impurities (mainly formaldehyde, acetaldehyde, acetone, formic acid and acetic acid), which have a rather high vapour pressure and are therefore not important for aerosol nucleation and growth, are reported to occur at rather low concentrations (below $1 \mathrm{ppbv}$ in total; see Schnitzhofer et al., 2014). This dark production of sulfuric acid is not the focus of this study but will be studied in more detail in the future. Here we focus on the investigation of the ion effect on the CIMS sulfuric acid measurements in the presence of OxOrgs and ions (GCR and pion beam) for both background (UV off) and nucleation experimental runs (UV on).

An interesting feature in Fig. 1b is that, during background measurements in the presence of the pion beam (07:30 UTC and later), the $\mathrm{HSO}_{4}^{-}$intensity measured by the mass spectrometer is increased by a factor of $\sim 2$ compared to neutral conditions (beam on or off but high voltage (HV) on). This observation indicates that there is an influence on the sulfuric acid measurement by additional $\mathrm{HSO}_{4}^{-}$ions detected by the CIMS under these conditions (beam on and HV off). Thus, the CIMS is not only detecting the $\mathrm{HSO}_{4}^{-}$ions being created in the CIMS flow reactor through reaction with $\mathrm{NO}_{3}^{-}$ions but also detecting additional $\mathrm{HSO}_{4}^{-}$ions coming directly from 


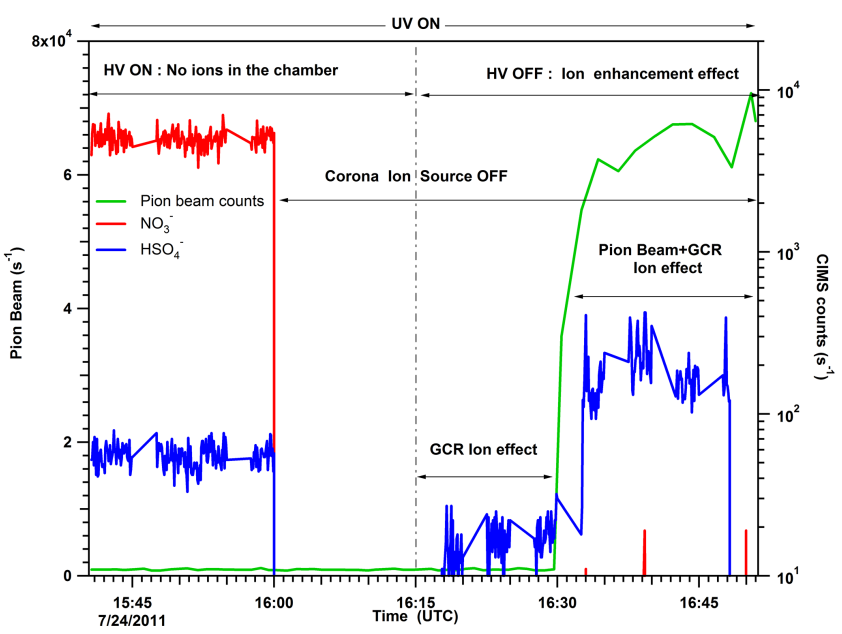

Figure 3. Example of the effect of the pion beam on the $\mathrm{HSO}_{4}^{-}$ count rate during a nucleation experiment. During the second part of this experiment (16:00 UTC and later), the CIMS corona ion source was switched off and only ions from the chamber were detected.

the chamber. In addition, the same effect is also taking place in the presence of the UV irradiation, where the production of sulfuric acid is taking place through $\mathrm{SO}_{2}$ oxidation by $\mathrm{OH}$ as well as stabilised Criegee intermediates (Riccobono et al., 2014). In both conditions (UV on and off), the observed enhancement of the detected $\mathrm{HSO}_{4}^{-}$ions is about a factor of 2.

The formation of $\mathrm{HSO}_{4}^{-}$ions within the chamber in the presence of GCRs or the pion beam is a result of ion-molecule reactions. The ions and free electrons created by the particle radiation rapidly interact with the gas molecules within the chamber and convert to complex positive and negative cluster ions and therefore induce radical chemical reactions (Kirkby, 2007). A chain of reactions is initiated by a rapid attachment of a free electron to an oxygen molecule $\mathrm{O}_{2}$ which possesses an appreciable electron affinity, leading to $\mathrm{O}_{2}^{-}$as the most important of the primary negative ions as shown in Reaction (R7). When an $\mathrm{O}_{2}^{-}$ion collides with a sulfuric acid molecule, it charges the molecule or cluster negatively by removing one proton (Almeida et al., 2013).

$$
\begin{aligned}
e^{-}+\mathrm{O}_{2} & \rightarrow \mathrm{O}_{2}^{-}+\mathrm{O}_{2} \\
\mathrm{O}_{2}^{-}+\mathrm{H}_{2} \mathrm{SO}_{4} & \rightarrow \mathrm{HO}_{2}+\mathrm{HSO}_{4}^{-}
\end{aligned}
$$

By activating the clearing field (CF), the influence of the $\mathrm{HSO}_{4}^{-}$ions from the chamber is directly confirmed (Fig. 1b). When the clearing field is switched on, the measured $\mathrm{HSO}_{4}^{-}$ signal drops by a factor of 2 within about $1 \mathrm{~s}$, which corresponds to the time to remove ions due to the presence of the strong electric field (Kirkby et al., 2011). The $\mathrm{H}_{2} \mathrm{SO}_{4}$ lifetime of $\sim 400$ to $500 \mathrm{~s}$ is substantially longer; therefore, the observed short lifetime of the increased $\mathrm{HSO}_{4}^{-}$signal confirms that ions are responsible for it and not neutral sulfuric acid.

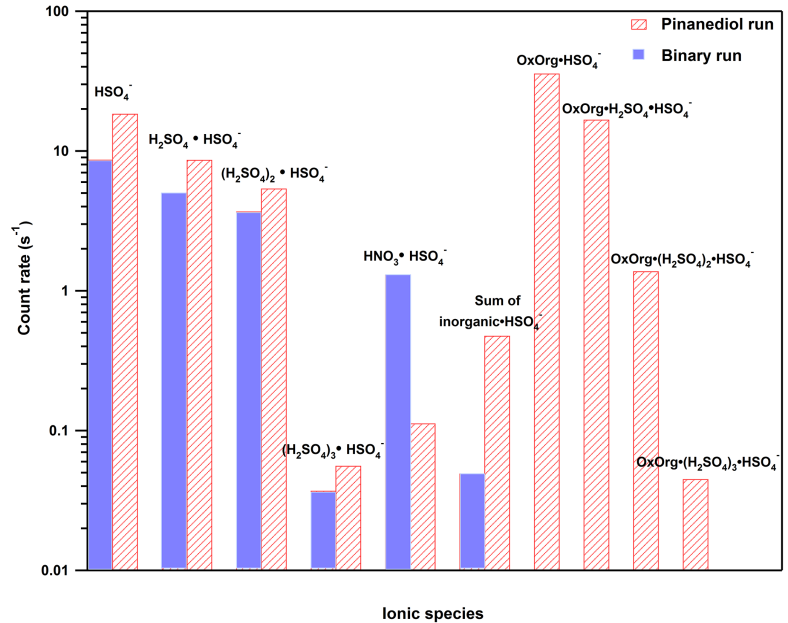

Figure 4. APi-TOF negative ion mass spectrum for a binary $\mathrm{H}_{2} \mathrm{SO}_{4}-\mathrm{H}_{2} \mathrm{O}$ (blue) and a pinanediol (red) nucleation experiment with almost identical sulfuric acid concentration $(6.6 \times$ $10^{6}$ molecule $\mathrm{cm}^{-3}$ ). The $\mathrm{HSO}_{4}^{-}$signal is increased by a factor of $\sim 2$, which confirms that these ions are detected with a higher sensitivity if PD is present. Clustering with OxOrg molecules and subsequent fragmentation can explain the elevated $\mathrm{HSO}_{4}^{-}$count rates.

In addition, a special experiment was performed by turning off the primary ion production in the CIMS corona ion source. The data in Fig. 3 unambiguously show that a substantial amount of $\mathrm{HSO}_{4}^{-}$ions can be detected if the corona ion source is turned off while the pion beam is turned on.

Moreover, another vital confirmation of the ion effect is provided by the APi-TOF mass spectrometer measurements. The APi-TOF mass spectrometer measures the composition and concentrations of negative ions at mass-to-charge ratios ranging from about 50 to $3300 \mathrm{Th}$ (Junninen et al., 2010; Schobesberger et al., 2013). A significant enhancement in the $\mathrm{HSO}_{4}^{-}$signal measured by the APi-TOF is shown in Fig. 4 for the presence of oxidised organics. In this figure, selected ion and cluster ion signals are displayed both for a binary $\left(\mathrm{H}_{2} \mathrm{SO}_{4}-\mathrm{H}_{2} \mathrm{O}\right)$ and a ternary pinanediol nucleation experiment with very similar conditions. The concentration of $\mathrm{H}_{2} \mathrm{SO}_{4}$ is about $6.6 \times 10^{7}$ molecule $\mathrm{cm}^{-3}$ for both conditions, whereas the pion beam intensity is about $10 \%$ higher for the $\mathrm{PD}$ experimental run. For the $\mathrm{H}_{2} \mathrm{SO}_{4}-\mathrm{H}_{2} \mathrm{O}$ nucleation experiment (binary run, shown in blue), the negative ion spectrum is clearly dominated by sulfuric acid and other inorganic compounds, which include water molecules associated with sulfuric acid or bisulfate. The strongest sulfate containing peak is from the $\mathrm{HSO}_{4}^{-}$ion $(\mathrm{m} / \mathrm{z}$ 97), which is seen to cluster with one, two or three $\mathrm{H}_{2} \mathrm{SO}_{4}$ molecules. The other main ions are $\mathrm{HSO}_{4}^{-}$clustering with $\mathrm{HNO}_{3}$ and other inorganic molecules. On the other hand, for the PD case (pinanediol run, shown in red), the most striking feature is that the $\mathrm{HSO}_{4}^{-}$ signal is raised by a factor of 2.2 even though the measured neutral sulfuric acid concentration is almost identical. Here, 
the most abundant ions were complex cluster ions containing oxidised $\mathrm{C}_{10} \mathrm{H}_{x} \mathrm{O}_{y}$ (where $x=12,14,16$ and $y=2-12$ ) organics and an $\mathrm{HSO}_{4}^{-}$ion as well as $0_{-2}^{-2}$ additional $\mathrm{H}_{2} \mathrm{SO}_{4}$ molecules.

\section{Discussion}

The APi-TOF mass spectrum clearly shows that $\mathrm{HSO}_{4}^{-}$can cluster efficiently with oxidised organic products if PD is present in the chamber. In the $\mathrm{H}_{2} \mathrm{SO}_{4}-\mathrm{H}_{2} \mathrm{O}$ nucleation experiments these bisulfate-OxOrg clusters are absent and the mass spectrum is dominated by $\mathrm{HSO}_{4}^{-}$. These observations suggest that the presence of OxOrg can enhance the transmission efficiency of the $\mathrm{HSO}_{4}^{-}$core ions through the sampling line of the APi-TOF and the CIMS. In particular, the sampling line transmission efficiency due to diffusional losses (Baron and Willeke, 2001) varies from 59 to $69 \%$ for $\mathrm{OxOrg} \cdot \mathrm{HSO}_{4}^{-}$and $\mathrm{OxOrg} \cdot\left(\mathrm{H}_{2} \mathrm{SO}_{4}\right)_{3} \cdot \mathrm{HSO}_{4}^{-}$, respectively, while the transmission efficiencies for the CIMS sampling line are $64 \%$ and $72 \%$ for the same ions. The increase in the mass of the $\mathrm{HSO}_{4}^{-}$. OxOrg ion complex leads to a reduction in the ion mobility, thereby enhancing the probability that the $\mathrm{HSO}_{4}^{-}$. OxOrg ions can eventually be detected. Fragmentation (i.e. evaporation of the OxOrg ligand) in the mass spectrometer leads to a rather strong increase in the $\mathrm{HSO}_{4}^{-}$signal. Since the CIMS uses a collision dissociation chamber (CDC) to detect only the core product ions and the mass range is limited to $\sim m / z, 250$, no mixed $\mathrm{HSO}_{4}^{-}$. OxOrg clusters are visible in the mass spectrum (see Fig. 5). The APi-TOF, however, appears to fragment the ions less strongly than the CIMS does and therefore the mixed $\mathrm{HSO}_{4}^{-}$. OxOrg clusters are clearly detected. A closer look at the sampling conditions of the CIMS reveals that, for conditions without organics, a major part of the bisulfate ions from the chamber is probably being lost before reaching the ion drift tube due to diffusion or electrostatic forces. Although there is no direct experimental evidence that ions are lost at one specific location in the CIMS sampling line and ion drift region, we can presume several possible locations for such effects to occur (see Fig. 6): (1) the entrance of the sampling probe, (2) the inner surface of the sampling line, (3) the section where the sampling line terminates and transitions into the CIMS drift tube and (4) the entrance to the vacuum chamber of the mass spectrometer (pinhole plate). Loss due to effects 3 and 4 are probably dominant for ions because electric fields separate the different regions of the CIMS inlet part (Kürten et al., 2011). Negatively charged ions in the sample gas experience a repulsing field when they enter the ion drift tube, and ions with high mobility can very likely be precipitated efficiently at the end of the sampling line. This loss mechanism is likely less strongly pronounced when OxOrgs are bound to $\mathrm{HSO}_{4}^{-}$and make the ion cluster less mobile. However, during binary and ternary $\left(\mathrm{NH}_{3}, \mathrm{DMA}\right)$ experiments, data from the APi-TOF show that $\mathrm{HSO}_{4}^{-}$does not bind with DMA or

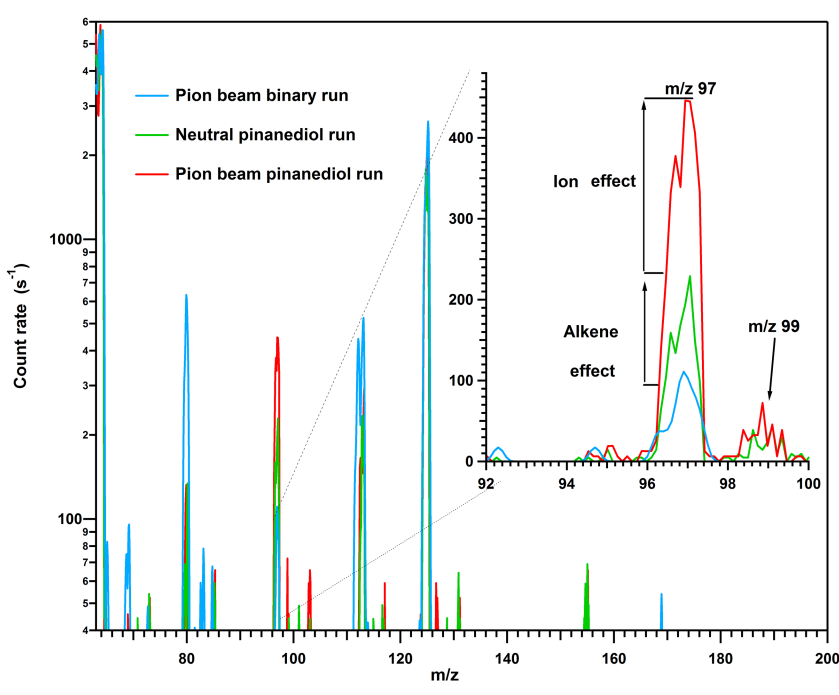

Figure 5. CIMS negative mass spectrum for a binary $\mathrm{H}_{2} \mathrm{SO}_{4}-\mathrm{H}_{2} \mathrm{O}$ (blue) and a pinanediol (red) experimental run in the presence of ions. For the pinanediol experimental run, the $\mathrm{HSO}_{4}^{-}$signal is enhanced by a factor of 2.25 in comparison to the equivalent neutral run (green).

$\mathrm{NH}_{3}$ molecules (Schobesberger et al., 2013). Therefore, in the presence of these gases there is no enhancement in the $\mathrm{HSO}_{4}^{-}$detection efficiency with the CIMS.

\section{Parameterisation of $\mathrm{H}_{2} \mathrm{SO}_{4}$ concentration during pinanediol experiments}

From the discussion above it is clear that ions had an effect on the measured sulfuric acid concentrations during ternary ioninduced nucleation experiments involving pinanediol. Only during neutral runs, while the high voltage of the clearing field electrodes is enabled, can the detected $\mathrm{HSO}_{4}^{-}$ion signal be directly used to determine the sulfuric acid concentration in the chamber. Any ion effect can be completely excluded as an additional source of $\mathrm{HSO}_{4}^{-}$ions, since under these conditions small ions are swept from the chamber within less than $1 \mathrm{~s}$. However, in order to derive the correct sulfuric acid concentration during the ion-induced nucleation experiments, one needs to be aware of ion effects and correct for them. Because not every ion-induced nucleation run was preceded by a neutral run with identical conditions, a parameterisation was derived, which can be applied to all ion-induced nucleation runs with pinanediol in order to derive a corrected sulfuric acid concentration. The parameterisation is only a simplification of the real sulfuric acid production process and it is not based on a physico-chemical modelled process. The chemistry behind the modelled processes is complicated, and not all affecting factors can be fully taken into account. For example, reactions in which $\mathrm{SO}_{2}$ is oxidised into sulfuric acid in the presence of UV radiation are known but the stabilised Criegee intermediates and the species involved, like 


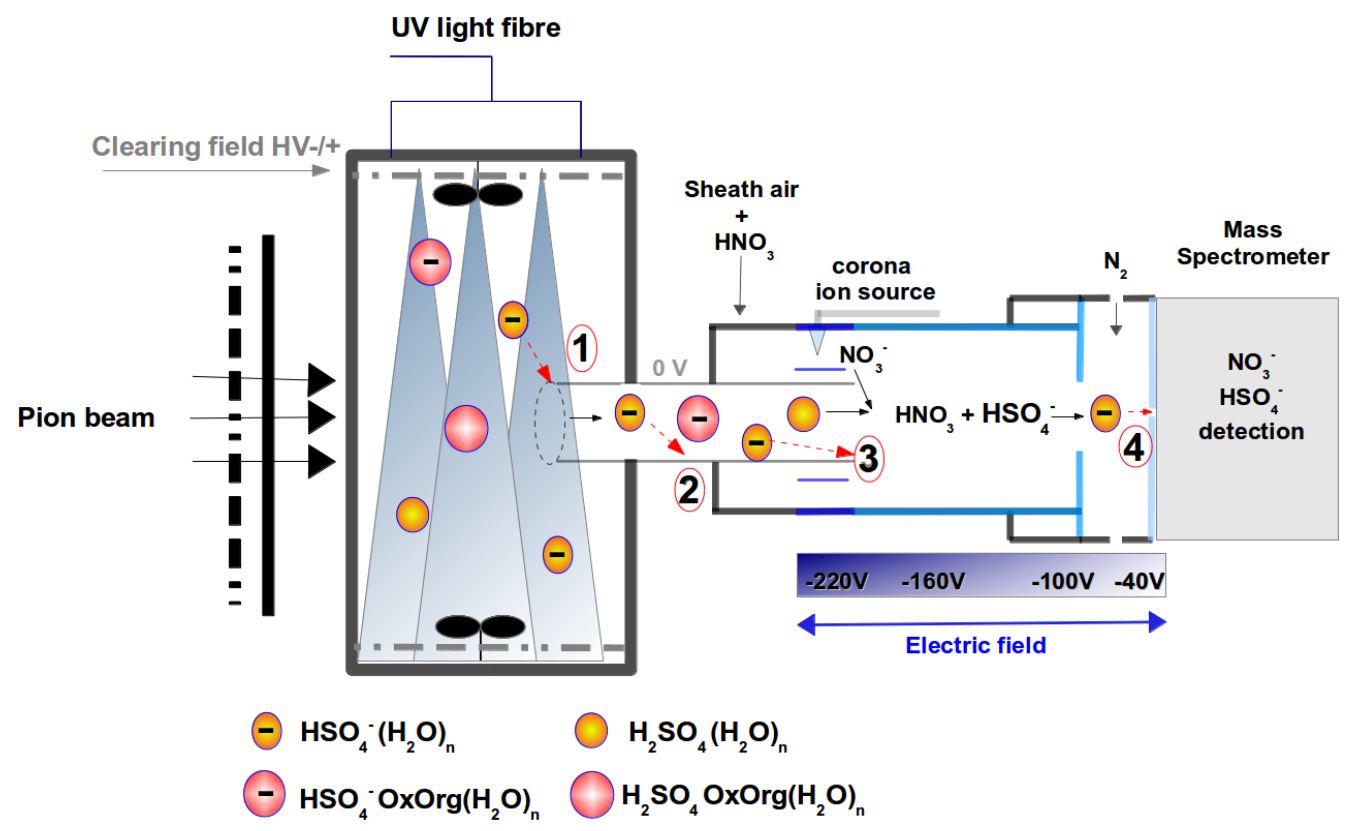

Figure 6. Schematic of the CLOUD chamber and the connected CIMS mass spectrometer. In a typical ion-induced binary (i.e. $\left.\mathrm{H}_{2} \mathrm{SO}_{4}+\mathrm{H}_{2} \mathrm{O}\right)$ experiment ( $\mathrm{HV}$ is switched off and the pion beam is on), not only $\mathrm{H}_{2} \mathrm{SO}_{4}$ neutral molecules but also $\mathrm{HSO}_{4}^{-}$ions are produced, which are usually attached to water molecules (yellow), while for pinanediol runs the $\mathrm{HSO}_{4}^{-}$ions are very likely bound to bigger OxOrg clusters (magenta). During binary experiments, the produced bisulfate ions are presumably efficiently lost before reaching the mass spectrometer. Losses can occur due to diffusion and/or electrostatic forces: (1) at the entrance of the sampling probe, (2) within the sampling line, (3) during the transfer into the CIMS ion drift region and (4) before entering the mass spectrometer.

$\mathrm{OH}$ radicals, also interact with several other compounds in the chamber, thus making it difficult to estimate how much sulfuric acid is actually formed when $\mathrm{OH}$ is not directly measured. In addition, DMA chemistry should also be considered since it reacts not only with $\mathrm{O}_{3}$, producing $\mathrm{OH}$ radicals (Tuazon et al., 1994), but also consumes OH radicals (Atkinson et al., 1978). The parameterisation provides an estimate of the net effect of these sinks and sources acting in the CLOUD chamber. The results of the parameterisation indicate that the derived $\left[\mathrm{H}_{2} \mathrm{SO}_{4}\right]$ is able to represent the "true" sulfuric acid concentration adequately. For the parameterisation of the sulfuric acid, a nonlinear regression analysis was used in this study in order to find a predictive model for the sulfuric acid concentration. Figure 7 shows that the predictive ability of the derived $\left[\mathrm{H}_{2} \mathrm{SO}_{4}\right]$ in an ion-free environment is good (red points), whereas for the ion-induced pinanediol case (green points) the observed deviation indicates the ion effect on the CIMS measurements. The developed parameterisation includes a combination of measured $\mathrm{O}_{3}, \mathrm{SO}_{2}$, relative humidity (RH), UV intensity, dimethylamine (DMA) and pinanediol (PD) mixing ratios. In more detail, the parameterisation relies on the following formula:

$$
\begin{aligned}
& {\left[\mathrm{H}_{2} \mathrm{SO}_{4}\right]_{\text {calc }, i}=} \\
& \mathrm{Bg}_{i}+\left(a_{0}+a_{1} \cdot \mathrm{UV}_{i}+a_{2} \cdot \mathrm{UV}_{i}{ }^{2}+a_{3} \cdot \mathrm{UV}_{i}{ }^{3}\right) \\
& \cdot\left(k \cdot \mathrm{RH}_{i}^{b} \cdot \mathrm{SO}_{2, i}{ }^{c} \cdot \mathrm{O}_{3, i}^{d}+g \cdot \mathrm{PD}_{i}{ }^{j}+m \cdot \mathrm{DMA}_{i}{ }^{l}\right) .
\end{aligned}
$$

Here, the index $i$ represents an averaged value for one experimental run denoting each of the parameters, UV represents the aperture of the UV light system in percent and RH represents the relative humidity in percent (temperature was constant at $278 \mathrm{~K}$ ). As for the gases used, $\mathrm{SO}_{2}$ is the sulfur dioxide mixing ratio in ppbv, $\mathrm{O}_{3}$ the ozone mixing ratio in ppbv, PD the pinanediol mixing ratio in pptv, DMA the dimethyalmine mixing ratio in pptv and $\mathrm{Bg}$ the background concentration of sulfuric acid just before an experimental run. Fitting the equation to the experimental data with the software IGOR yields the coefficients shown in Table 1 (coefficient values $\pm 95 \%$ confidence interval). From the comparison between parameterised and experimentally determined $\mathrm{H}_{2} \mathrm{SO}_{4}$ concentrations for the neutral runs, it is shown that the data are in good agreement $\left(R^{2}=0.963\right)$ (Fig. 7), which indicates that the parameterisation with a standard error of $\pm 6.3 \times 10^{5} \mathrm{~cm}^{-3}$ can also be applied to the GCR and charged beam experimental runs when no information on the $\left[\mathrm{H}_{2} \mathrm{SO}_{4}\right]$ under neutral conditions is available. In order to confirm the good agreement between the 


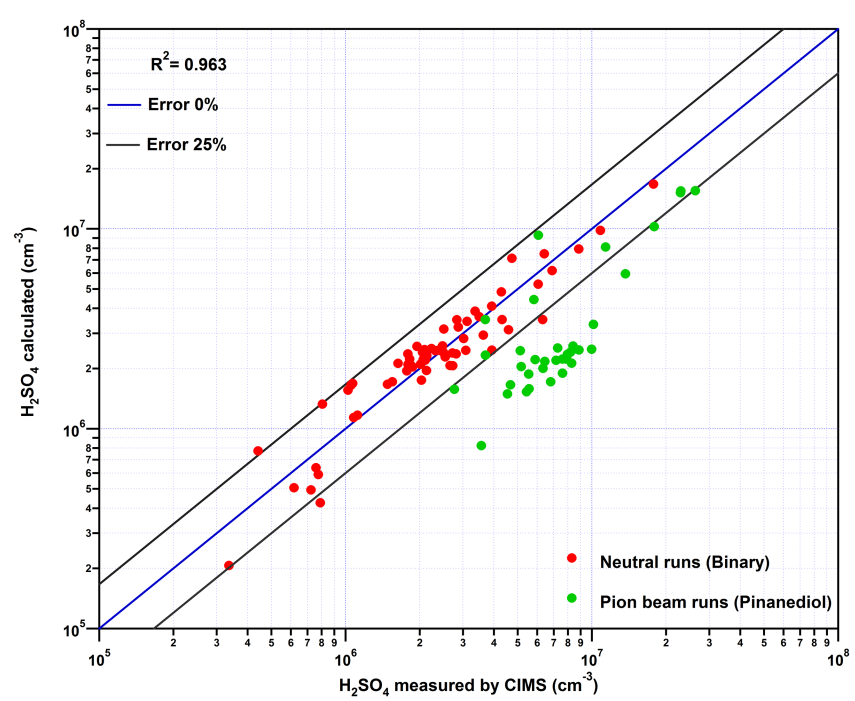

Figure 7. Calculated $\left[\mathrm{H}_{2} \mathrm{SO}_{4}\right]$ vs. measured $\left[\mathrm{H}_{2} \mathrm{SO}_{4}\right]$ for binary and ternary organic nucleation runs. The presence of ions during the pinanediol runs leads to an excess of measured $\mathrm{H}_{2} \mathrm{SO}_{4}$. The deviation between the parameterised and the measured concentrations for the charged runs indicates the magnitude of the ion effect on the CIMS measurement.

Table 1. Coefficients $( \pm \mathrm{SD})$ of parameters used in the $\mathrm{H}_{2} \mathrm{SO}_{4}$ parameterisation formula.

\begin{tabular}{cl}
\hline Parameter & Value \\
\hline$k$ & $2.3 \times 10^{-4} \pm 1.4 \times 10^{-6}$ \\
$a_{0}$ & $51593 \pm 1$ \\
$a_{1}$ & $12953 \pm 1$ \\
$a_{2}$ & $-209.99 \pm 0.001$ \\
$a_{3}$ & $1.0934 \pm 1 \times 10^{-5}$ \\
$b$ & $2.0934 \pm 1 \times 10^{-5}$ \\
$c$ & $0.82661 \pm 0.127$ \\
$d$ & $0.56574 \pm 0.0869$ \\
$g$ & $-1.9897 \times 10^{-5} \pm 0.00025$ \\
$m$ & $-0.747 \pm 2.58$ \\
$j$ & $1.2766 \pm 1.25$ \\
$l$ & $-0.087045 \pm 1$ \\
\hline
\end{tabular}

parameterised and experimental data, in Fig. 8 the experimental neutral runs are displayed along with their equivalent GCR and pion beam experimental runs that followed in sequence. The parameterised sulfuric acid concentration was of advantage not only for the current study but also for further analysis of nucleation studies from the CLOUD experiments (Riccobono et al., 2014).

\section{Atmospheric implications}

A question related to the discussed observations is to what degree atmospheric measurements could be affected by this

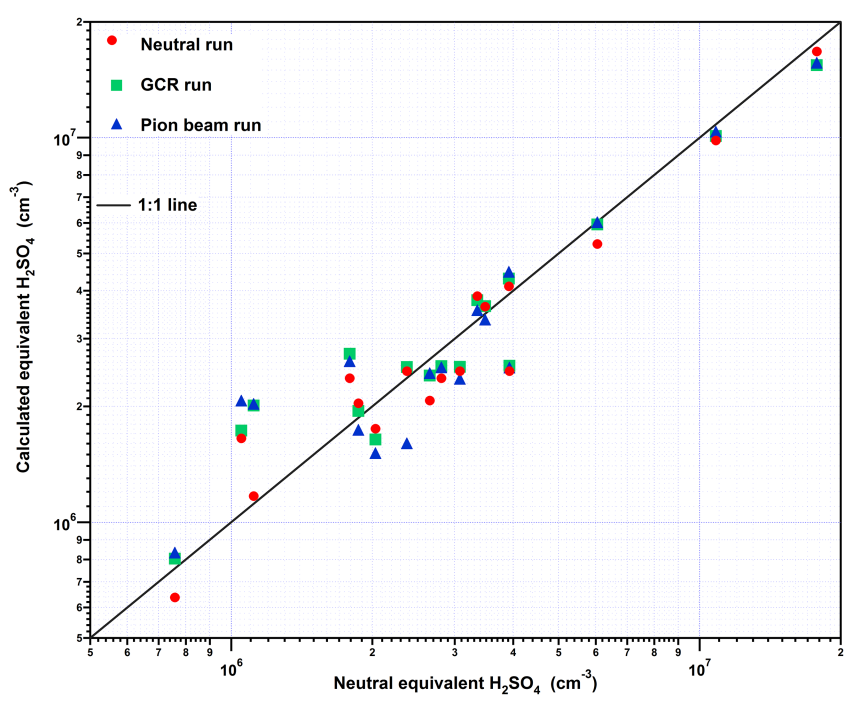

Figure 8. For some GCR (galactic cosmic ray) and pion beam runs a neutral run preceded where the conditions of the chamber were identical. This figure compares the parameterised $\left[\mathrm{H}_{2} \mathrm{SO}_{4}\right]$ for the GCR and beam runs to the value from the neutral stage. The good agreement indicates that the parameterisation can also be applied to the GCR and beam runs when no information on the $\left[\mathrm{H}_{2} \mathrm{SO}_{4}\right]$ under neutral conditions is available.

phenomenon. Because the CLOUD-04 experiment simulated atmospherically relevant oxidation products to a great extent (Riccobono et al., 2014), there was a need for further investigation of the ambient bisulfate ion enhancement effect on the CIMS measurements. As a consequence of our observations, we developed an ion precipitator, which was installed inside of a new ambient sampling line (total length $1 \mathrm{~m}$ and flow rate $1800 \mathrm{~L} \mathrm{~min}^{-1}$ ) and was located just before the entrance to the ion source. The ion precipitator uses a high voltage in the range of $2 \mathrm{kV}$ and an applied grounding located opposite to the high voltage, resulting in an electrostatic field which effectively removes ions from the ambient sample flow. This adjustment in the CIMS sampling line was developed in order to investigate the effect of ions on atmospheric measurements of gaseous sulfuric acid and for future CLOUD experiments to avoid the additional signal of $\mathrm{HSO}_{4}^{-}$ions coming from the chamber.

During August and September 2011, the CIMS instrument participated in the PARADE campaign, which took place at the Kleiner Feldberg Taunus Observatory near Frankfurt, Germany. Figure 9 shows the measurement of sulfuric acid during daytime. In the lower part of the graph the sulfuric acid concentration is displayed along with the ion precipitator setting. The ion precipitator is set to be active every $15 \mathrm{~min}$ in order to investigate whether an effect from ambient ions can be detected. The performed measurements do not indicate a significant influence of the ion effect, and we conclude that the contribution of the atmospheric $\mathrm{HSO}_{4}^{-}$ions is very small during the PARADE measurements. Turning off 

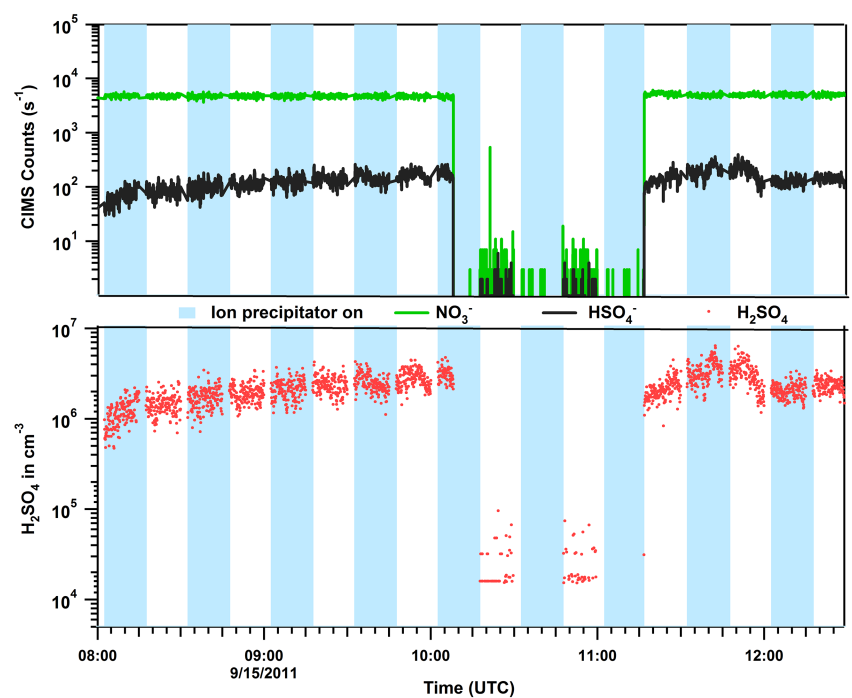

Figure 9. Daytime atmospheric $\left[\mathrm{H}_{2} \mathrm{SO}_{4}\right]$ measurements along with the setting of the ion precipitator. In the upper graph, the count rates of the primary ions $\mathrm{NO}_{3}^{-}$and the $\mathrm{HSO}_{4}^{-}$product ions are displayed while the ion precipitator is enabled every $15 \mathrm{~min}$. While the corona ion source is on, the signal of both $\mathrm{NO}_{3}^{-}$and $\mathrm{HSO}_{4}^{-}$is not noticeably influenced by the ion precipitator. When the CIMS corona ion source is off, the maximum contribution of the ambient $\mathrm{HSO}_{4}^{-}$ions can be evaluated to be several $10^{4}$ molecule $\mathrm{cm}^{-3}$.

the corona ion source allows for estimation of the maximum contribution due to ambient ions (lower panel of Fig. 9). If the ion precipitator is enabled, all bisulfate ions are effectively eliminated $\left(0\right.$ counts $\left.\mathrm{s}^{-1}\right)$. In contrast, for the case of having both the corona source and the ion precipitator switched off, the slight increase in the bisulfate ion signal ( $\sim 4$ to 5 counts $\mathrm{s}^{-1}$ ) is noticeably observed relative to the previous case. Using this measured $\mathrm{HSO}_{4}^{-}$ion count rate together with the typical primary ion count rate, one can translate the effect of the ambient ions to be equivalent to several $10^{4}$ molecule $\mathrm{cm}^{-3}$ during normal operation. This is typically smaller than the CIMS noise level.

Nevertheless, earlier studies have shown, for example, that significant ion production can occur in the vicinity of highvoltage power lines (Eisele, 1989a, b; Matthews et al., 2010). Therefore, in other environments with a strong local source of ions, it is not clear whether CIMS measurements could potentially be affected more strongly. Still, during the entire PARADE campaign, the GCR ion effect was negligible for the CIMS $\mathrm{H}_{2} \mathrm{SO}_{4}$ concentration measurements. Hence, since the exact nature of the bisulfate transmission enhancing ligand that is leading to the enhanced ion detection has not yet been identified, for other environments, sampling conditions, ion source geometries and the applied electric fields, it cannot be ruled out that sulfuric acid atmospheric measurements or chamber experiments are affected to some extent.

\section{Conclusions}

In this study the effect of ions on CIMS sulfuric acid concentration measurements in the presence of the organic vapour pinanediol (PD) and its oxidised products has been presented. We measured the sulfuric acid concentration during the CLOUD-04 campaign, in experiments studying nucleation from $\mathrm{H}_{2} \mathrm{SO}_{4}-\mathrm{H}_{2} \mathrm{O}$ (binary) and $\mathrm{H}_{2} \mathrm{SO}_{4}-\mathrm{H}_{2} \mathrm{O}-\mathrm{NH}_{3}, \mathrm{H}_{2} \mathrm{SO}_{4}-\mathrm{H}_{2} \mathrm{O}-\mathrm{DMA}, \mathrm{H}_{2} \mathrm{SO}_{4}-\mathrm{H}_{2} \mathrm{O}$ DMA-PD or $\mathrm{H}_{2} \mathrm{SO}_{4}-\mathrm{H}_{2} \mathrm{O}-\mathrm{PD}$ (ternary) systems of vapours within the CLOUD chamber, where all parameters of the experiment were well controlled. In the presence of pinanediol organic vapour and its oxidised products, and while ions are introduced into the chamber, there is an amount of $\mathrm{HSO}_{4}^{-}$ produced within the chamber which is effectively detected, leading to an overestimation of the $\mathrm{H}_{2} \mathrm{SO}_{4}$ monomer concentration by the CIMS measurement. We performed tests of the CIMS instrument in order to verify that we count more $\mathrm{HSO}_{4}^{-}$ions in the presence of chamber ions. Moreover, data from the APi-TOF confirmed the enhanced detection efficiency of sulfuric acid ions, indicating a ligand that decreases the mobility of the bisulfate ion complex. As the $\mathrm{HSO}_{4}^{-}$ions affect the CIMS $\mathrm{H}_{2} \mathrm{SO}_{4}$ measurement, we developed a parameterisation of the CIMS sulfuric acid measurements for the neutral case, when all ions are removed from the chamber within $<1 \mathrm{~s}$ and therefore no $\mathrm{HSO}_{4}^{-}$is present in the chamber. Later on, the parameterisation was applied to the CIMS sulfuric acid measurements during GCR and charged pion beam experimental runs. In this way, we corrected the CIMS sulfuric acid measurements for the ion effect. We were also interested in the atmospheric implications of this observation, so for this reason we performed atmospheric sulfuric acid measurements with the CIMS mass spectrometer, which showed that the ion effect was negligible for ground-based ambient measurements. Nevertheless, for future chamber experiments, an ion precipitator should in general be applied in front of the CIMS for regular operation. Furthermore, more dedicated studies should be carried out to investigate the ion effect of complex bisulfate ions on the sulfuric acid CIMS measurements in the presence of oxidised organics, focusing on the transmission efficiency of the bisulfate ions to the mass spectrometer.

Acknowledgements. We thank CERN for supporting CLOUD with important technical and financial resources and provision of a particle beam from the proton synchrotron. This research was funded by the EC 7th Framework Programme (Marie Curie Initial Training Network "CLOUD-ITN", grant no. 215072), the German Federal Ministry of Education and Research (project no. 01LK0902A), the ERC Advanced Grant "ATMNUCLE" (no. 227463), and the Academy of Finland via the Centre of Excellence programme (project no. 1118615, 272041) and grant no. 1133872 , 272851 .

Edited by: J. Abbatt 


\section{References}

Almeida, J., Schobesberger, S., Kürten, A., Ortega, I. K., Kupiainen-Määttä, O., Praplan, A. P., Adamov, A., Amorim, A., Bianchi, F., Breitenlechner, M., David, A., Dommen, J., Donahue, N. M., Downard, A., Dunne, E., Duplissy, J., Ehrhart, S., Flagan, R. C., Franchin, A., Guida, R., Hakala, J., Hansel, A., Heinritzi, M., Henschel, H., Jokinen, T., Junninen, H., Kajos, M., Kangasluoma, J., Keskinen, H., Kupc, A., Kurtén, T., Kvashin, A. N., Laaksonen, A., Lehtipalo, K., Leiminger, M., Leppä, J., Loukonen, V., Makhmutov, V., Mathot, S., McGrath, M. J., Nieminen, T., Olenius, T., Onnela, A., Petäjä, T., Riccobono, F., Riipinen, I., Rissanen, M., Rondo, L., Ruuskanen, T., Santos, F. D., Sarnela, N., Schallhart, S., Schnitzhofer, R., Seinfeld, J. H., Simon, M., Sipilä, M., Stozhkov, Y., Stratmann, F., Tomé, A., Tröstl, J., Tsagkogeorgas, G., Vaattovaara, P., Viisanen, Y., Virtanen, A., Vrtala, A., Wagner, P. E., Weingartner, E., Wex, H., Williamson, C., Wimmer, D., Ye, P., Yli-Juuti, T., Carslaw, K. S., Kulmala, M., Curtius, J., Baltensperger, U., Worsnop, D. R., Vehkamäki, H., and Kirkby, J.: Molecular understanding of sulphuric acid-amine particle nucleation in the atmosphere, Nature, 502, 359-363, doi:10.1038/nature12663, 2013.

Atkinson, R., Perry, R. A., Pitts Jr., J. N.: Rate constants for the reactions of the hydroxyl radical with dimethylamine, trimethylamine, and ethylamine over the temperature range 298-426 K, J. Chem. Phys., 68, 1850-1853, 1978.

Baron, P. A. and Willeke, K.: Aerosol Measurement: Principles, Techniques, and Applications, John Wiley and Sons, 2nd Edn., p. 580, 2001.

Benson, D. R., Erupe, M. E., and Lee, S.-H.: Laboratorymeasured $\mathrm{H}_{2} \mathrm{SO}_{4}-\mathrm{H}_{2} \mathrm{O}-\mathrm{NH}_{3}$ ternary homogeneous nucleation rates: Initial observations, Geophys Res. Lett., 36, L15818, doi:10.1029/2009GL038728, 2009.

Berresheim, H., Elste, T., Plass-Dülmer, C., Eisele, F. L., and Tanner, D. J.: Chemical ionization mass spectrometer for long-term measurements of atmospheric $\mathrm{OH}$ and $\mathrm{H}_{2} \mathrm{SO}_{4}$, Int. J. Mass Spectrom., 202, 91-109, doi:10.1016/S1387-3806(00)00233-5, 2000.

Curtius, J.: Nucleation of atmospheric aerosol particles, Comptes Rendus Phys., 7, 1027-1045, doi:10.1016/j.crhy.2006.10.018, 2006.

Duplissy, J., Enghoff, M. B., Aplin, K. L., Arnold, F., Aufmhoff, H., Avngaard, M., Baltensperger, U., Bondo, T., Bingham, R., Carslaw, K., Curtius, J., David, A., Fastrup, B., Gagné, S., Hahn, F., Harrison, R. G., Kellett, B., Kirkby, J., Kulmala, M., Laakso, L., Laaksonen, A., Lillestol, E., Lockwood, M., Mäkelä, J., Makhmutov, V., Marsh, N. D., Nieminen, T., Onnela, A., Pedersen, E., Pedersen, J. O. P., Polny, J., Reichl, U., Seinfeld, J. H., Sipilä, M., Stozhkov, Y., Stratmann, F., Svensmark, H., Svensmark, J., Veenhof, R., Verheggen, B., Viisanen, Y., Wagner, P. E., Wehrle, G., Weingartner, E., Wex, H., Wilhelmsson, M., and Winkler, P. M.: Results from the CERN pilot CLOUD experiment, Atmos. Chem. Phys., 10, 1635-1647, doi:10.5194/acp-101635-2010, 2010.

Eisele, F. L.: Natural and atmospheric negative ions in the troposphere, J. Geophys. Res.-Atmos., 94, 2183-2196, 1989a.

Eisele, F. L.: Natural and transmission line produced positive ions, J. Geophys. Res.-Atmos., 94, 6309-6318, 1989 b.

Eisele, F. L. and Tanner, D. J.: Measurement of the gas phase concentration of $\mathrm{H}_{2} \mathrm{SO}_{4}$ and methane sulfonic acid and estimates of
$\mathrm{H}_{2} \mathrm{SO}_{4}$ production and loss in the atmosphere, J. Geophys. Res.Atmos., 98, 9001-9010, doi:10.1029/93JD00031, 1993.

Hanson, D. R. and Eisele, F. L.: Diffusion of $\mathrm{H}_{2} \mathrm{SO}_{4}$ in Humidified Nitrogen: Hydrated $\mathrm{H}_{2} \mathrm{SO}_{4}$, J. Phys. Chem. A, 104, 1715-1719, 2000.

Huey, L. G.: Measurement of trace atmospheric species by chemical ionization mass spectrometry: Speciation of reactive nitrogen and future directions, Mass Spectrom. Rev., 26, 166-184, doi:10.1002/mas.20118, 2007.

Junninen, H., Ehn, M., Petäjä, T., Luosujärvi, L., Kotiaho, T., Kostiainen, R., Rohner, U., Gonin, M., Fuhrer, K., Kulmala, M., and Worsnop, D. R.: A high-resolution mass spectrometer to measure atmospheric ion composition, Atmos. Meas. Tech., 3, 1039-1053, doi:10.5194/amt-3-1039-2010, 2010.

Kirkby, J.: Cosmic rays and climate, Surv. Geophys., 28, 333-375, 2007.

Kirkby, J., Curtius, J., Almeida, J., Dunne, E., Duplissy, J., Ehrhart, S., Franchin, A., Gagné, S., Ickes, L., Kürten, A., Kupc, A., Metzger, A., Riccobono, F., Rondo, L., Schobesberger, S., Tsagkogeorgas, G., Wimmer, D., Amorim, A., Bianchi, F., Breitenlechner, M., David, A., Dommen, J., Downard, A., Ehn, M., Flagan, R. C., Haider, S., Hansel, A., Hauser, D., Jud, W., Junninen, H., Kreissl, F., Kvashin, A., Laaksonen, A., Lehtipalo, K., Lima, J., Lovejoy, E. R., Makhmutov, V., Mathot, S., Mikkilä, J., Minginette, P., Mogo, S., Nieminen, T., Onnela, A., Pereira, P., Petäjä, T., Schnitzhofer, R., Seinfeld, J. H., Sipilä, M., Stozhkov, Y., Stratmann, F., Tomé, A., Vanhanen, J., Viisanen, Y., Vrtala, A., Wagner, P. E., Walther, H., Weingartner, E., Wex, H., Winkler, P. M., Carslaw, K. S., Worsnop, D. R., Baltensperger, U., and Kulmala, M.: Role of sulphuric acid, ammonia and galactic cosmic rays in atmospheric aerosol nucleation, Nature, 476, 429-433, doi:10.1038/nature10343, 2011.

Kroll, J. H., Sahay, S. R., Anderson, J. G., Demerjian, K. L., and Donahue, N. M.: Mechanism of HOx formation in the gas-phase ozone-alkene reaction. 2. Prompt versus thermal dissociation of carbonyl oxides to form OH, J. Phys. Chem. A, 105, 4446-4457, 2001.

Kuang, C., McMurry, P. H., McCormick, A. V., and Eisele, F. L.: Dependence of nucleation rates on sulfuric acid vapor concentration in diverse atmospheric locations, J. Geophys. Res.-Atmos., 113, D10209, doi:10.1029/2007JD009253, 2008.

Kulmala, M.: How Particles Nucleate and Grow, Science, 302, 1000-1001, doi:10.1126/science.1090848, 2003.

Kulmala, M., Vehkamäki, H., Petäjä, T., Dal Maso, M., Lauri, A., Kerminen, V.-M., Birmili, W., and McMurry, P. H.: Formation and growth rates of ultrafine atmospheric particles: a review of observations, J. Aerosol Sci., 35, 143-176, doi:10.1016/j.jaerosci.2003.10.003, 2004.

Kupc, A., Amorim, A., Curtius, J., Danielczok, A., Duplissy, J., Ehrhart, S., Walther, H., Ickes, L., Kirkby, J., Kürten, A., Lima, J. M., Mathot, S., Minginette, P., Onnela, A., Rondo, L., and Wagner, P. E.: A fibre-optic UV system for $\mathrm{H}_{2} \mathrm{SO}_{4}$ production in aerosol chambers causing minimal thermal effects, J. Aerosol Sci., 42, 532-543, doi:10.1016/j.jaerosci.2011.05.001, 2011.

Kürten, A., Rondo, L., Ehrhart, S., and Curtius, J.: Performance of a corona ion source for measurement of sulfuric acid by chemical ionization mass spectrometry, Atmos. Meas. Tech., 4, 437-443, doi:10.5194/amt-4-437-2011, 2011. 
Kürten, A., Rondo, L., Ehrhart, S., and Curtius, J.: Calibration of a Chemical Ionization Mass Spectrometer for the Measurement of Gaseous Sulfuric Acid, J. Phys. Chem. A, 116, 6375-6386, doi:10.1021/jp212123n, 2012.

Lovejoy, E. R., Curtius, J., and Froyd, K. D.: Atmospheric ioninduced nucleation of sulfuric acid and water, J. Geophys. Res.Atmos., 109, D08204, doi:10.1029/2003JD004460, 2004.

Matthews, J. C., Ward, J. P., Keitch, P. A., and Henshaw, D. L.: Corona ion induced atmospheric potential gradient perturbations near high voltage power lines, Atmos. Environ., 44, 5093-5100, doi:10.1016/j.atmosenv.2010.09.007, 2010.

Mauldin III, R. L., Berndt, T., Sipilä, M., Paasonen, P., Petäjä, T., Kim, S., Kurtén, T., Stratmann, F., Kerminen, V.-M., and Kulmala, M.: A new atmospherically relevant oxidant of sulphur dioxide, Nature, 488, 193-196, doi:10.1038/nature11278, 2012.

Merikanto, J., Spracklen, D. V., Pringle, K. J., and Carslaw, K. S.: Effects of boundary layer particle formation on cloud droplet number and changes in cloud albedo from 1850 to 2000, Atmos. Chem. Phys., 10, 695-705, doi:10.5194/acp-10-695-2010, 2010.

Metzger, A., Verheggen, B., Dommen, J., Duplissy, J., Prevot, A. S. H., Weingartner, E., Riipinen, I., Kulmala, M., Spracklen, D. V., Carslaw, K. S., and Baltensperger, U.: Evidence for the role of organics in aerosol particle formation under atmospheric conditions, Proc. Natl. Acad. Sci., 107, 6646-6651, doi:10.1073/pnas.0911330107, 2010.

Petäjä, T., Mauldin, III, R. L., Kosciuch, E., McGrath, J., Nieminen, T., Paasonen, P., Boy, M., Adamov, A., Kotiaho, T., and Kulmala, M.: Sulfuric acid and $\mathrm{OH}$ concentrations in a boreal forest site, Atmos. Chem. Phys., 9, 7435-7448, doi:10.5194/acp9-7435-2009, 2009.

Praplan, A. P., Bianchi, F., Dommen, J., and Baltensperger, U.: Dimethylamine and ammonia measurements with ion chromatography during the CLOUD4 campaign, Atmos. Meas. Tech., 5, 2161-2167, doi:10.5194/amt-5-2161-2012, 2012.

Riccobono, F., Rondo, L., Sipilä, M., Barmet, P., Curtius, J., Dommen, J., Ehn, M., Ehrhart, S., Kulmala, M., Kürten, A., Mikkilä, J., Paasonen, P., Petäjä, T., Weingartner, E., and Baltensperger, U.: Contribution of sulfuric acid and oxidized organic compounds to particle formation and growth, Atmos. Chem. Phys., 12, 9427-9439, doi:10.5194/acp-12-9427-2012, 2012.

Riccobono, F., Schobesberger, S., Scott, C. E., Dommen, J., Ortega, I. K., Rondo, L., Almeida, J., Amorim, A., Bianchi, F., Breitenlechner, M., David, A., Downard, A., Dunne, E. M., Duplissy, J., Ehrhart, S., Flagan, R. C., Franchin, A., Hansel, A., Junninen, H., Kajos, M., Keskinen, H., Kupc, A., Kürten, A., Kvashin, A. N., Laaksonen, A., Lehtipalo, K., Makhmutov, V., Mathot, S., Nieminen, T., Onnela, A., Petäjä, T., Praplan, A. P., Santos, F. D., Schallhart, S., Seinfeld, J. H., Sipilä, M., Spracklen, D. V., Stozhkov, Y., Stratmann, F., Tomé, A., Tsagkogeorgas, G., Vaattovaara, P., Viisanen, Y., Vrtala, A., Wagner, P. E., Weingartner, E., Wex, H., Wimmer, D., Carslaw, K. S., Curtius, J., Donahue, N. M., Kirkby, J., Kulmala, M., Worsnop, D. R., and Baltensperger, U.: Oxidation products of biogenic emissions contribute to nucleation of atmospheric particles, Science, 344, 717-721, doi:10.1126/science.1243527, 2014.
Riipinen, I., Sihto, S.-L., Kulmala, M., Arnold, F., Dal Maso, M., Birmili, W., Saarnio, K., Teinilä, K., Kerminen, V.-M., Laaksonen, A., and Lehtinen, K. E. J.: Connections between atmospheric sulphuric acid and new particle formation during QUEST III-IV campaigns in Heidelberg and Hyytiälä, Atmos. Chem. Phys., 7, 1899-1914, doi:10.5194/acp-7-1899-2007, 2007.

Schnitzhofer, R., Metzger, A., Breitenlechner, M., Jud, W., Heinritzi, M., De Menezes, L.-P., Duplissy, J., Guida, R., Haider, S., Kirkby, J., Mathot, S., Minginette, P., Onnela, A., Walther, H., Wasem, A., Hansel, A., and the CLOUD Team: Characterisation of organic contaminants in the CLOUD chamber at CERN, Atmos. Meas. Tech., 7, 2159-2168, doi:10.5194/amt-7-2159-2014, 2014.

Schobesberger, S., Junninen, H., Bianchi, F., Lönn, G., Ehn, M., Lehtipalo, K., Dommen, J., Ehrhart, S., Ortega, I. K., Franchin, A., Nieminen, T., Riccobono, F., Hutterli, M., Duplissy, J., Almeida, J., Amorim, A., Breitenlechner, M., Downard, A. J., Dunne, E. M., Flagan, R. C., Kajos, M., Keskinen, H., Kirkby, J., Kupc, A., Kürten, A., Kurtén, T., Laaksonen, A., Mathot, S., Onnela, A., Praplan, A. P., Rondo, L., Santos, F. D., Schallhart, S., Schnitzhofer, R., Sipilä, M., Tomé, A., Tsagkogeorgas, G., Vehkamäki, H., Wimmer, D., Baltensperger, U., Carslaw, K. S., Curtius, J., Hansel, A., Petäjä, T., Kulmala, M., Donahue, N. M., and Worsnop, D. R.: Molecular understanding of atmospheric particle formation from sulfuric acid and large oxidized organic molecules, Proc. Natl. Acad. Sci., 110, 17223-17228, doi:10.1073/pnas.1306973110, 2013.

Tanner, D. J., Jefferson, A., and Eisele, F. L.: Selected ion chemical ionization mass spectrometric measurement of $\mathrm{OH}$, J. Geophys. Res.-Atmos., 102, 6415-6425, doi:10.1029/96JD03919, 1997.

Tuazon, E. C., Atkinson, R., Aschmann, S. M., and Arey, J.: Kinetics and products of the gas-phase reactions of $\mathrm{O}_{3}$ with amines and related compounds, Res. Chem. Intermed., 20, 303-320, 1994.

Viggiano, A. A. and Arnold, F.: Stratospheric sulfuric acid vapor: New and updated measurements, J. Geophys. Res.-Ocean., 88, 1457-1462, doi:10.1029/JC088iC02p01457, 1983.

Voigtländer, J., Duplissy, J., Rondo, L., Kürten, A., and Stratmann, F.: Numerical simulations of mixing conditions and aerosol dynamics in the CERN CLOUD chamber, Atmos. Chem. Phys., 12, 2205-2214, doi:10.5194/acp-12-2205-2012, 2012.

Wimmer, D., Lehtipalo, K., Franchin, A., Kangasluoma, J., Kreissl, F., Kürten, A., Kupc, A., Metzger, A., Mikkilä, J., Petäjä, T., Riccobono, F., Vanhanen, J., Kulmala, M., and Curtius, J.: Performance of diethylene glycol-based particle counters in the sub-3 nm size range, Atmos. Meas. Tech., 6, 1793-1804, doi:10.5194/amt-6-1793-2013, 2013.

Zhang, R., Suh, I., Zhao, J., Zhang, D., Fortner, E. C., Tie, X., Molina, L. T., and Molina, M. J.: Atmospheric New Particle Formation Enhanced by Organic Acids, Science 304, 1487-1490, 2004. 